\title{
Somatostatin Inhibits Excitatory Transmission at Rat Hippocampal Synapses via Presynaptic Receptors
}

\author{
Stefan Boehm and Heinrich Betz \\ Max-Planck-Institut für Hirnforschung, Abteilung Neurochemie, D-60528 Frankfurt/Main, Germany
}

Somatostatin is one of the major peptides in interneurons of the hippocampus. It is believed to play a role in memory formation and to reduce the susceptibility of the hippocampus to seizurelike activity. However, at the cellular level, the actions of somatostatin on hippocampal neurons are still controversial, ranging from inhibition to excitation. In the present study, we measured autaptic currents of hippocampal neurons isolated in singleneuron microcultures. Somatostatin and the analogous peptides seglitide and octreotide reduced glutamatergic, but not GABAergic, autaptic currents via pertussis toxin-sensitive G-proteins. This effect was observed whether autaptic currents were mediated by NMDA or non-NMDA glutamate receptors. Furthermore, somatostatin did not affect currents evoked by the direct application of glutamate, but reduced the frequency of spontaneously occurring excitatory autaptic currents. These results show that presynaptic somatostatin receptors of the
$\mathrm{SRIF}_{1}$ family inhibit glutamate release at hippocampal synapses. Somatostatin, seglitide, and octreotide also reduced the frequency of miniature excitatory postsynaptic currents in mass cultures without affecting their amplitudes. In addition, all three agonists inhibited voltage-activated $\mathrm{Ca}^{2+}$ currents at neuronal somata, but failed to alter $\mathrm{K}^{+}$currents, effects that were also abolished by pertussis toxin. Thus, presynaptic somatostatin receptors in the hippocampus selectively inhibit excitatory transmission via $\mathrm{G}$-proteins of the $\mathrm{G}_{\mathrm{i}} / \mathrm{G}_{\mathrm{o}}$ family and through at least two separate mechanisms, the modulation of $\mathrm{Ca}^{2+}$ channels and an effect downstream of $\mathrm{Ca}^{2+}$ entry. This presynaptic inhibition by somatostatin may provide a basis for its reportedly anticonvulsive action.

Key words: autapses; hippocampus; somatostatin; G-proteins; glutamate release; $\mathrm{Ca}^{2+}$ current
Somatostatin, a cyclic tetradecapeptide, was initially identified as a hypothalamic peptide that regulates growth hormone secretion from cells of the anterior pituitary gland (Brazeau et al., 1973). In subsequent years, somatostatin was described as a neurotransmitter and neuromodulator (for review, see Reichlin, 1983). Somatostatin is synthesized in numerous neurons throughout the brain (Johansson et al., 1984) and is released in a $\mathrm{Ca}^{2+}$-dependent manner (Iversen et al., 1978). The peptide is thought to be involved in various complex functions of the CNS, such as the sensation of pain (Kuriashi et al., 1985) and the formation of memory (Matsuoka et al., 1994). In addition, levels of somatostatin are altered in several human brain dysfunctions, such as senile dementia of the Alzheimer type (Davies et al., 1980) and temporal lobe epilepsy (Robbins et al., 1991).

Brain regions that are particularly rich in somatostatincontaining neurons include the neocortex and the hippocampal formation (Johansson et al., 1984). In the hippocampus, somatostatin is a co-transmitter in inhibitory, GABA-containing interneurons (Freund and Buzsaki, 1996). These GABAergic neurons were shown to release somatostatin in a $\mathrm{Ca}^{2+}$-dependent manner in vitro (Fontana et al., 1996) and in vivo (Mathe et al., 1993). However, it remains controversial whether somatostatin in the hippocampus is inhibitory, as is GABA, or excitatory. Inhibitory

Received Jan. 27, 1997; revised March 12, 1997; accepted March 17, 1997.

This study was supported by the Fonds der Chemischen Industrie. S.B. is the recipient of a Schrödinger fellowship from the Austrian Science Foundation. We thank R. Harvey, S. Huck, and V. O'Connor for helpful comments on this manuscript and G. Koth, A. Hendricks, and A. Motejlek for perfect technical assistance.

Correspondence should be addressed to Dr. Stefan Boehm, Max-Planck-Institut für Hirnforschung, Abteilung Neurochemie, Deutschordenstrasse 46, D-60528 Frankfurt/Main, Germany

Copyright (C) 1997 Society for Neuroscience $\quad 0270-6474 / 97 / 174066-10 \$ 05.00 / 0$ effects have been reported, for instance, in rat hippocampal slices (Pittman and Siggins, 1981; Moore et al., 1988), but excitatory actions of somatostatin have also been observed in the very same preparation (Dodd and Kelly, 1978). Similarly, somatostatin has been found to both excite and inhibit cortical neurons in tissue culture (Delfs and Dichter, 1983).

The reasons for these discrepancies have remained elusive, and several explanations may be considered. (1) Somatostatin may act via at least five distinct receptors (Hoyer et al., 1995; Reisine and Bell, 1995), and different receptors can mediate opposing actions of somatostatin even in a single neuron (Wang et al., 1990). Transcripts for all five receptors have been detected in rat hippocampus (Thoss et al., 1995). (2) Contrasting effects of somatostatin may result from a direct and an indirect action, respectively. Such indirect actions of somatostatin might be mediated by acetylcholine (Araujo et al., 1990) or dopamine (Chesselet and Reisine, 1983), the release of which can be triggered by this neuropeptide. (3) Opposite effects may arise when a neurotransmitter activates either pre- or postsynaptic receptors. Presynaptic receptors for somatostatin have been described previously in peripheral, sympathetic (Boehm and Huck, 1996), and parasympathetic (Gray et al., 1989), but not central, neurons.

The present study was performed in search of presynaptic somatostatin receptors in hippocampal neurons. To avoid indirect effects of somatostatin that may arise in neuronal networks, we investigated synaptic transmission at autapses formed by neurons that grow in isolation on microislands of glial cells. Autapses of such microculture neurons display functional characteristics similar to those of conventional synapses in vitro (Bekkers and Stevens, 1991; Tong et al., 1996). Our results indicate that pre- 
synaptic somatostatin receptors regulate transmission at excitatory hippocampal synapses.

\section{MATERIALS AND METHODS}

Cell culture. Hippocampi were dissected from neonatal Wistar rats, cut into small pieces, and incubated in papain (Worthington, Freehold, NJ, 1 $\mathrm{mg} / \mathrm{ml}$ in L-15 Leibovitz medium) for $30 \mathrm{~min}$ at $36^{\circ} \mathrm{C}$. After removal of the enzyme, tissue fragments were washed three times in $25 \%$ fetal calf serum in PBS. Thereafter, a single cell suspension was obtained by trituration in DMEM (Life Technologies, Berlin, Germany) containing $10 \%$ fetal calf serum (Integro, Zaandam, Holland) and $5 \mu \mathrm{g} / \mathrm{ml}$ insulin, $5 \mu \mathrm{g} / \mathrm{ml}$ transferrin, $5 \mathrm{ng} / \mathrm{ml}$ Na-selenite (Boehringer Mannheim, Mannheim, Germany), $10 \mathrm{~nm}$ progesterone, $2 \mathrm{~mm} \mathrm{MgSO}_{4}, 25,000 \mathrm{IU} / 1$ penicillin, and $25 \mathrm{mg} / \mathrm{l}$ streptomycin (Sigma, Deisenhofen, Germany). For high-density mass cultures, $\sim 50,000$ cells were seeded into microchambers created by glass rings (inner diameter, $10 \mathrm{~mm}$ ) placed in the center of $35 \mathrm{~mm}$ culture dishes (Nunclon \#150350) that had been coated with poly-D-lysine (Sigma, $1 \mathrm{mg} / \mathrm{ml}$ ). To obtain microisland cultures, $\sim 100,000$ cells were plated in $35 \mathrm{~mm}$ culture dishes prepared as follows. The dishes were first coated with $0.15 \%$ agarose and sterilized by UV irradiation. Thereafter, a mixture of poly-D-ornithine $(1 \mathrm{mg} / \mathrm{ml})$ and collagen $(4$ $\mathrm{mg} / \mathrm{ml}$ ) was sprayed onto the dishes under sterile conditions with a chromatography microatomizer (NeoLab, Heidelberg, Germany). All cultures were kept in a water-saturated $5 \% \mathrm{CO}_{2}$ atmosphere at $37^{\circ} \mathrm{C}$.

After 3-5 d, $3 \mu \mathrm{M}$ cytosine arabinoside (Sigma) was added to the culture medium to reduce the proliferation of non-neural cells. After $6 \mathrm{~d}$ in vitro, microislands cultures were treated with $100 \mu \mathrm{M}$ glutamate in recording solution (see below) containing $2 \mathrm{mM} \mathrm{Ca}^{2+}$, but no $\mathrm{Mg}^{2+}$, for $60 \mathrm{~min}$ at room temperature; this procedure removed all neurons to generate pure glial microislands. On day 7, $\sim 40,000$ freshly dissociated hippocampal cells were seeded onto these microislands. Cytosine arabinoside $(3 \mu \mathrm{M})$ was added again after 3-5 d. Media were not changed until the cultures were used for experiments.

Electrophysiological recordings of autaptic currents. Single, isolated neurons in microcultures were used for electrophysiological experiments after 8-16 d in vitro. Currents were recorded from neuronal somata in the whole-cell configuration of the patch-clamp technique (Hamill et al., $1981)$ at room temperature $\left(20^{\circ}-24^{\circ} \mathrm{C}\right)$. Unless stated otherwise, neurons were clamped at a holding potential of $-70 \mathrm{mV}$ and depolarized for 1-2 $\mathrm{msec}$ to $0 \mathrm{mV}$. Autaptic currents were evoked by this stimulation protocol every $30 \mathrm{sec}$. Spontaneously occurring excitatory autaptic currents (SEACs) were recorded in sweeps of 1-2 sec at a potential of $-70 \mathrm{mV}$ Stimulation and current recordings were obtained with an EPC-9 (HEKA, Lambrecht, Germany) amplifier linked to an Atari Mega STE computer controlled by HEKA software.

Electrodes were pulled from borosilicate glass capillaries (Hilgenberg, Malsfeld, Germany) with a Zeitz DMZ Universal Puller (Zeitz Instruments, Augsburg, Germany) to yield tip resistances of 1-3 M $\Omega$. Series resistances after whole-cell formation $(5-20 \mathrm{M} \Omega$ ) were monitored regularly throughout recordings and compensated for by $60-90 \%$.

Pipettes were filled with a solution containing (in mM): K-glutamate 100, K-gluconate 40, $\mathrm{CaCl}_{2}$ 1.6, EGTA 10, HEPES 10, Mg-ATP 2, and Li-GTP 2, adjusted to $\mathrm{pH} 7.3$ with $\mathrm{NaOH}$. Unless stated otherwise, the bathing solution consisted of (in mM): $\mathrm{NaCl} 140, \mathrm{KCl} 6, \mathrm{CaCl}_{2} 3, \mathrm{MgCl}_{2}$ 2, glucose 20, and HEPES 10, adjusted to $\mathrm{pH} 7.4$ with $\mathrm{NaOH}$. Neurons under investigation were superfused continuously with this solution, containing test drugs if appropriate. Superfusion was performed with a DAD-12 (Adams and List, Westbury, NY) drug application system.

Electrophysiological recordings of miniature excitatory postsynaptic currents (mEPSCs) and glutamate-evoked currents. MEPSCs and glutamateinduced currents in microculture or mass culture neurons were recorded with the same settings as those used for autaptic currents (see above). As with microcultures, mass cultures were used for experiments $8-16 \mathrm{~d}$ after plating. The bathing solution (see above) contained $1 \mu \mathrm{M}$ TTX and 1-2 mM kynurenic acid to minimize the probability of polysynaptic excitations. The neuron from which mEPSCs were recorded and its surrounding were superfused continuously with a solution lacking kynurenic acid to permit the occurrence of mEPSCs, but containing $1 \mu \mathrm{M}$ TTX and 30 $\mu \mathrm{M}$ bicuculline methiodide (BMI) to suppress evoked EPSCs and inhibitory postsynaptic currents, respectively.

Currents through glutamate receptors were elicited by the direct application of $100 \mu \mathrm{M}$ glutamate via the DAD-12 superfusion device in either the absence or the continuous presence of somatostatin.

Electrophysiological recordings of voltage-activated $\mathrm{Ca}^{2+}$ and $\mathrm{K}^{+}$currents. Voltage-activated $\mathrm{Ca}^{2+}$ and $\mathrm{K}^{+}$currents from hippocampal neu- rons in mass culture were recorded after $7-14 \mathrm{~d}$ in vitro, as described previously for sympathetic neurons (Boehm and Huck, 1996a; Boehm et al., 1996). The internal solution used to measure $\mathrm{Ca}^{2+}$ currents contained (in $\mathrm{mM}$ ): NMDG 115 , tetraethylammonium chloride $20, \mathrm{CaCl}_{2} 1.6$, EGTA 10, glucose 10, HEPES 20, Mg-ATP 2, and Li-GTP 2, adjusted to pH 7.3 with $\mathrm{HCl}$. For the recording of voltage-dependent $\mathrm{K}^{+}$currents, as well as for the determination of the resting membrane potential, the internal (pipette) solution contained (in $\mathrm{mM}$ ) $\mathrm{KCl} 140, \mathrm{CaCl}_{2}$ 1.59, EGTA 10, HEPES 10, Mg-ATP 2, and Li-GTP 2, adjusted to $\mathrm{pH} 7.3$ with KOH. The bathing solution was the same as above and contained $1 \mu \mathrm{M}$ TTX to block $\mathrm{Na}^{+}$channels and $100 \mu \mathrm{M} \mathrm{Cd}^{2+}$ to block $\mathrm{Ca}^{2+}$ channels when $\mathrm{K}^{+}$currents were measured. Unless stated otherwise, $\mathrm{K}^{+}$and $\mathrm{Ca}^{2+}$ currents were evoked every $15-20 \mathrm{sec}$ by depolarizations from $-80 \mathrm{mV}$ to $0 \mathrm{mV}$. For these experiments, we used an EPC-7 amplifier (List Medical, Darmstadt, Germany) linked to an Olivetti personal computer under the control of the PClamp (5.0) software (Axon Instruments, Tujunga, CA).

Calculations and statistics. Autaptic currents as well as voltage-activated $\mathrm{Ca}^{2+}$ currents occasionally showed considerable rundown. To take this into account, current amplitudes in the presence (B) of somatostatin and other test drugs were compared with those obtained before application (A) and after washout (C); drug effects were evaluated either as percent of control $[=200 \times \mathrm{B} /(\mathrm{A}+\mathrm{C})]$ or as percent of inhibition $[=100 \times(1-$ $2 \mathrm{~B} /\{\mathrm{A}+\mathrm{C}\})]$. MEPSCs or SEACs were evaluated off-line by the TAC program (Instrutech, Elmont, NY) running on an Atari Mega STE computer. This program automatically detects peaks that exceed a certain threshold. Thresholds were adjusted for each cell by analysis of traces obtained in the presence of $10 \mu \mathrm{M}$ CNQX, which entirely blocked all glutamate-mediated synaptic currents in the presence of $\mathrm{Mg}^{2+}$ (Fig. 1A).

Unless stated otherwise, results are presented as arithmetic means \pm SEM; $n=$ number of cells. Differences between data points were evaluated by the unpaired Student's $t$ test. Concentration-response curves were fitted to experimentally obtained data by the ALLFIT program (DeLean et al., 1978), which also determines differences between single concentration-response curves by simultaneous fitting with shared parameters and subsequent calculation of the $F$ statistic on the resulting "extra sum of squares."

Materials. Somatostatin, TTX, BMI, kynurenic acid, and pertussis toxin (PTX) were obtained from Sigma (Deisenhofen, Germany), and CNQX and AP5 from Tocris Cookson (Bristol, UK). Octreotide was a gift from Sandoz (Basel, Switzerland) and seglitide was donated by Merck, Sharp and Dohme (Vienna, Austria).

\section{RESULTS \\ Effects of somatostatin on autaptic currents in microisland neurons}

Conflicting results have been obtained with somatostatin when applied to hippocampal neurons in networks, for example, in slice preparations or conventional primary cell cultures (Dodd and Kelly, 1978; Pittman and Siggins, 1981; Moore et al., 1988). Therefore, we used single hippocampal neurons on microislands of glial cells. Such microisland neurons are isolated from any other neuron and form only synaptic connections onto themselves, so-called autapses (Bekkers and Stevens, 1991). When such neurons were shortly (1-2 msec) depolarized to $\sim 0 \mathrm{mV}$, either excitatory (EAC) or inhibitory (IAC) autaptic currents could be observed. These two types of currents could be easily distinguished by the following criteria. (1) At negative holding potentials, EACs were always inward directed, whereas IACs reversed at approximately $-60 \mathrm{mV}$ (Fig. $1 A-C$ ), as shown previously under similar experimental conditions (Bekkers and Stevens, 1991). (2) When $2 \mathrm{mM} \mathrm{Mg}^{2+}$ was present in the superfusion buffer to block NMDA receptors at negative potentials, EACs were abolished by $10 \mu \mathrm{M}$ CNQX, whereas IACs were blocked by $30 \mu \mathrm{M}$ BMI (Fig. $1 A-C)$. Hence, the currents were mediated by non-NMDA glutamate receptors and by $\mathrm{GABA}_{\mathrm{A}}$ receptors, respectively. (3) EACs decayed rapidly and monoexponentially with a mean time constant of $6.0 \pm 0.3 \mathrm{msec}(n=19)$ when NMDA receptors were blocked by $2 \mathrm{mM} \mathrm{Mg}^{2+}$, whereas IACs had prolonged durations 
A
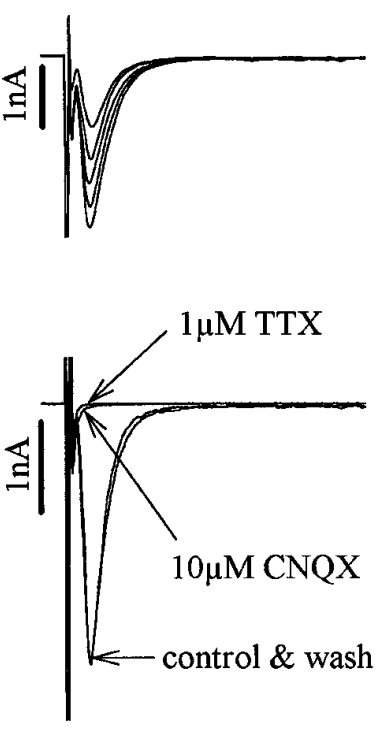

Figure 1. Autaptic currents of hippocampal microisland neurons and their modulation by somatostatin. $A$ and $B$ show EACs and IACs, respectively, recorded from two different neurons by the stimulation protocol shown in $C$. Currents in the bottom panels were recorded before (control), during, and after (wash) the application of $1 \mu \mathrm{M}$ TTX $(A, B), 10 \mu \mathrm{M}$ CNQX $(A)$, and 30 $\mu \mathrm{M}$ BMI $(B)$, respectively. The time scale in $C$ applies to the currents shown in $A, B, D$, and $E . D$, EACs measured at a holding potential of $-70 \mathrm{mV}$ before (control), during, and after (wash) the application of $1 \mu \mathrm{M}$ somatostatin. $E$ shows the same sequence of recordings obtained in a neuron displaying IACs measured at a holding potential of -40 $\mathrm{mV} . F$ summarizes the effects of $1 \mu \mathrm{M}$ somatostatin on EACs and IACs. The boxes encompass the median 25th through 75th percentiles and contain a line marking the median 50th percentile point. The caps of the error bars indicate the median 10th and 90th percentiles.
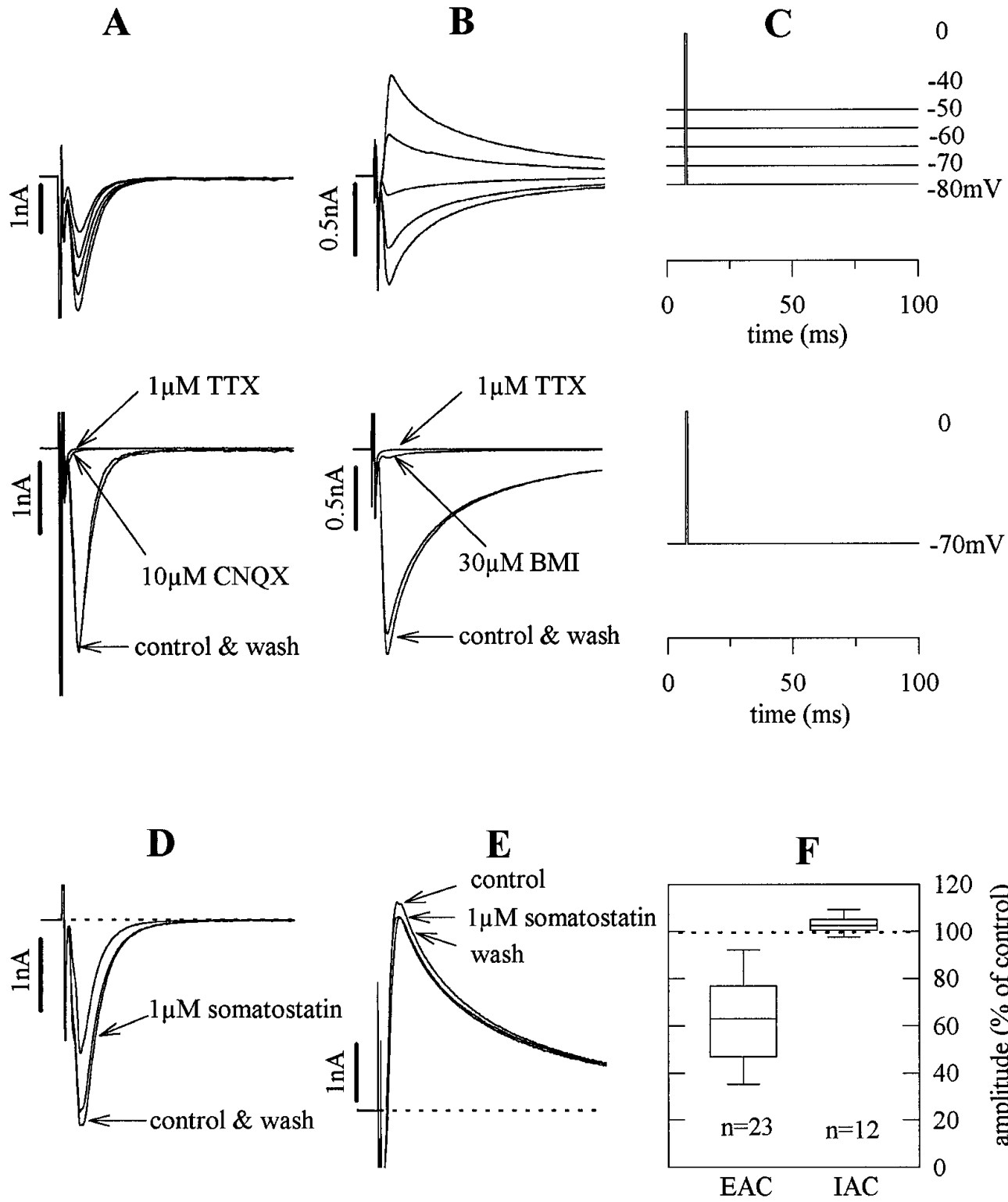

with double exponential decay and time constants of $12.4 \pm 1.2$ and $65.0 \pm 6.3 \mathrm{msec}(n=13)$.

EACs were measured routinely at holding potentials of -70 $\mathrm{mV}$ and had a mean peak current amplitude of $-5.7 \pm 0.6 \mathrm{nA}$ $(n=48)$. The time lag between the end of depolarizations and the peak amplitude amounted to $7.2 \pm 0.3 \mathrm{msec}(n=48)$. IACs were determined as outward currents at $-40 \mathrm{mV}$ and had peak current amplitudes of $1.8 \pm 0.8 \mathrm{nA}(n=17)$. The time between depolarization and peak IACs was $6.3 \pm 0.4 \mathrm{msec}(n=17)$. Both EACs and IACs were abolished in the presence of either $0.3 \mu \mathrm{M}$ TTX (Fig. $1 A, B)$ or $30 \mu \mathrm{M} \mathrm{Cd}{ }^{2+}$ (data not shown).

Somatostatin $(1 \mu \mathrm{M})$ reduced EACs (Fig. $1 D, F)$ in an entirely reversible manner. This effect varied considerably between single neurons, yielding inhibition from down to $32 \%$ of control amplitudes to just $93 \%$ of control. Conversely, IACs were not affected by somatostatin (Fig. $1 E, F$ ). The inhibitory action of somatostatin on EACs was half-maximal at $12 \mathrm{nM}$ and reached a mean maximum of $38 \%$ inhibition (Fig. $2 A$ ).

Native somatostatin receptors can be divided into two subfamilies, $\mathrm{SRIF}_{1}$ and $\mathrm{SRIF}_{2}$, which are distinguished by agonist affin- ities and/or potencies; subtype-selective antagonists are currently not available (Hoyer et al., 1995; Reisine and Bell, 1995). Two short synthetic somatostatin analogs, seglitide (Veber et al., 1981) and octreotide (Tran et al., 1985), have most frequently been used to characterize somatostatin receptors. These two peptides have

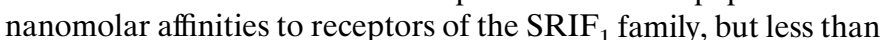
micromolar affinities for the $\mathrm{SRIF}_{2}$ family (Hoyer et al., 1994, 1995; Reisine and Bell, 1995). In rat hippocampal microisland neurons, seglitide and octreotide, like somatostatin, reduced EACs. Seglitide caused half-maximal inhibition at $10.2 \mathrm{nM}$, and octreotide at $9.4 \mathrm{~nm}$. These values are not different from those obtained with somatostatin, indicating equipotency of the three agonists. From the concentration-response curves in Figure $2 A$, seglitide and octreotide appeared to yield less maximal inhibition than somatostatin. However, when the three agonists were applied to the same set of neurons, they all produced $\sim 25 \%$ inhibition (Fig. 2B) and were thus equieffective.

Somatostatin receptors most commonly exert their cellular effects via PTX-sensitive G-proteins (Rens-Domiano and Reisine, 1992), although PTX-insensitive effects of somatostatin have also 
A

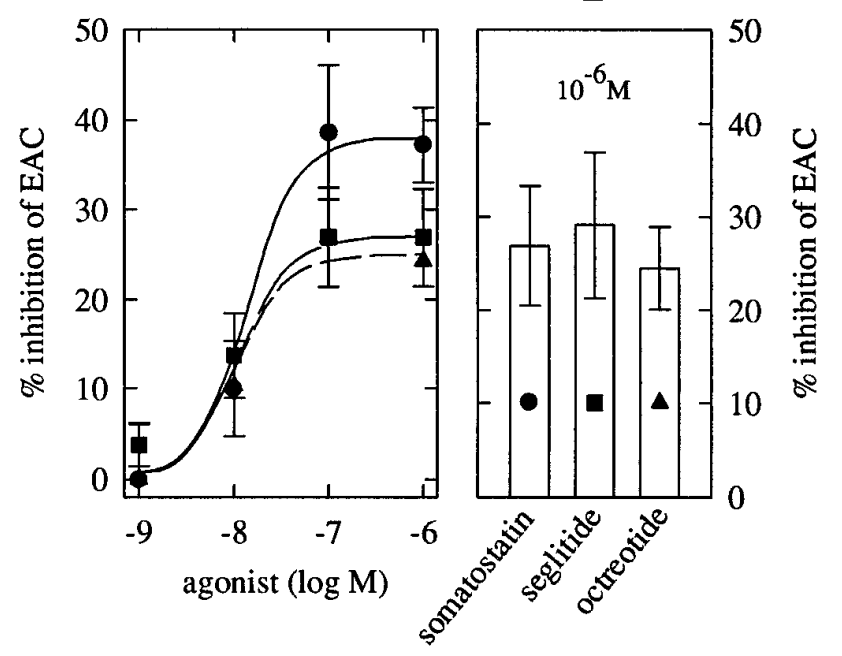

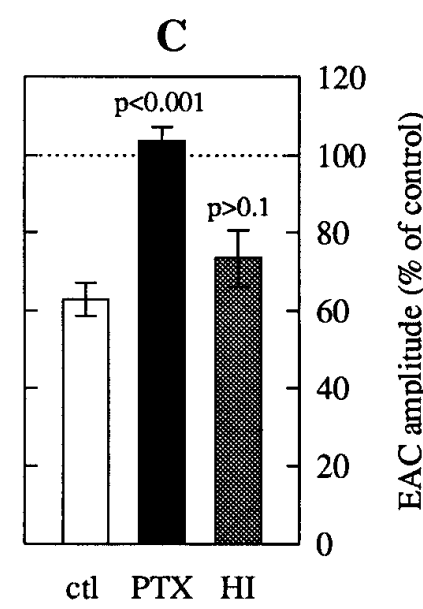

Figure 2. Pharmacological characterization of somatostatin receptors mediating the inhibition of EACs. $A$, Concentration-response curves for the reduction of EACs (measured as shown in Fig. $1 D$ ) by somatostatin (circles, $n=7-23$, with the exception of $1 \mathrm{nM}$, for which $n=3$ ), seglitide (squares, $n=5-9$ ), and octreotide (triangles, $n=5-9$ ). Data for the three agonists are pooled from different neurons, but not every neuron could be exposed to all agonist concentrations. $B$, Inhibition of EACs by $1 \mu \mathrm{M}$ somatostatin, seglitide, and octreotide in a common set of neurons $(n=5)$. $C$, Effects of $1 \mu \mathrm{M}$ somatostatin on EACs in neurons treated with $200 \mathrm{ng} / \mathrm{ml}$ PTX for $\leq 24 \mathrm{hr}$ $(P T X)$, in neurons treated with heatinactivated $\left(95^{\circ} \mathrm{C}\right.$ for $\left.5 \mathrm{~min}\right)$ PTX $(H I)$, and in control (untreated) neurons $(c t l)$. Levels of significance for the difference between the results obtained in pretreated and in untreated neurons, respectively, are indicated above the bars. been reported for central neurons of the rat (Twery et al., 1991). When microisland neurons had been treated with $200 \mathrm{ng} / \mathrm{ml}$ PTX for at least $24 \mathrm{hr}$, somatostatin failed to inhibit EACs (Fig. 2C). Peak amplitudes of EACs $(-5.3 \pm 2.2 \mathrm{nA} ; n=6)$ and the delay between depolarization and peak currents $(7.2 \pm 0.6 \mathrm{msec} ; n=6)$ were not altered after PTX treatment, compared with untreated neurons. Treatment of neurons with heat-inactivated $\left(95^{\circ} \mathrm{C}\right.$ for 5 min) PTX did not alter the inhibitory effect of somatostatin (Fig. $2 C)$. Thus, the inhibition of EACs by somatostatin was mediated by $\mathrm{G}$-proteins of the $\mathrm{G}_{\mathrm{i}} / \mathrm{G}_{\mathrm{o}}$ group.

\section{Somatostatin acts at presynaptic receptors}

Several mechanisms could underlie the selective inhibition of EACs, but not IACs, by somatostatin. For example, a blockade of postsynaptic non-NMDA glutamate receptors might have mediated these effects. In hypothalamic neurons, somatostatin receptors have been shown to modulate currents through non-NMDA glutamate receptors (Gardette et al., 1995). To find out whether effects of somatostatin arose from a postsynaptic action on a certain glutamate receptor, the following experiments were performed.

\section{Experiment 1}

EACs were evoked under conditions that either favor (no $\mathrm{Mg}^{2+}$, $10 \mu \mathrm{M}$ glycine $)$ or prevent $\left(2 \mathrm{mM} \mathrm{Mg}^{2+}\right.$, no glycine $)$ the activation of NMDA receptors. When activation of NMDA receptors was permitted, EACs showed a prolonged duration with biexponential decay kinetics (Fig. $3 A$ ); the two time constants of decay were $6.1 \pm 0.5 \mathrm{msec}$ (which is identical to the time constant obtained in the presence of $\left.\mathrm{Mg}^{2+}\right)$ and $211.7 \pm 7.3 \mathrm{msec}(n=6)$, respectively. The late phases $(>30 \mathrm{msec}$ after the depolarization) of these prolonged EACs were carried by NMDA receptors, as evidenced by their blockade in the presence of $50 \mu \mathrm{M}$ AP5 (Fig. $3 A$ ). Somatostatin $(1 \mu \mathrm{M})$ reduced peak EACs when NMDA receptors were involved $(49.5 \pm 11.9 \%$ of control) to the same extent as when NMDA receptors were blocked $(47.7 \pm 8.9 \%$ of control; $n=6$ ). Furthermore, pure NMDA receptor-carried EACs (measured between 50 and $60 \mathrm{msec}$ after the end of the depolarizing voltage step) were also inhibited to the same extent $(43.2 \pm 11.1 \%$ of control; $n=6$ ) (Fig. $3 B$ ). Hence, EACs were reduced by somatostatin irrespective of the type of glutamate receptor mediating the autaptic currents.

\section{Experiment 2}

Glutamate $(100 \mu \mathrm{M})$ was applied directly to hippocampal neurons in mass cultures in either the absence or the presence of somatostatin. The peptide failed to alter glutamate-evoked currents (Fig. 3C). In the presence of $1 \mu \mathrm{M}$ somatostatin, the rapidly decaying peak currents were $94.7 \pm 5.8 \%$ of control, and the subsequent plateau currents were $100.7 \pm 1.5 \%$ of control $(n=$ $6)$. These results indicated that somatostatin did not interfere with the function of non-NMDA glutamate receptors in rat hippocampal neurons.

The most plausible explanation for these observations is a presynaptic site of action for somatostatin. To corroborate this hypothesis, we recorded evoked and SEACs from single microisland neurons. As shown in Figure 4, $1 \mu \mathrm{M}$ somatostatin not only reduced the amplitude of evoked EACs, but also the frequency of SEACs. In three microisland neurons tested, somatostatin increased inter-SEAC intervals by $66.5 \pm 12.8 \%(p<0.05$ in each cell) without affecting mean SEAC amplitudes $(112.3 \pm 2.6 \%$ of control; $p>0.1$ in each cell). After washout of the peptide, inter-SEAC intervals returned to $109.4 \pm 12.3 \%$ of control, and mean SEAC amplitudes were $117.6 \pm 2.1 \%$ of control. These results are entirely compatible with a merely presynaptic site of action for somatostatin (Scanziani et al., 1992; Scholz and Miller, 1992; Trudeau et al., 1996).

\section{Somatostatin receptors reduce the probability of spontaneous glutamate release in mass cultures}

The results on synaptic currents presented above were all obtained in microisland neurons. To reveal whether presynaptic somatostatin receptors might also operate in a network of rat hippocampal neurons, mEPSCs were recorded from neurons in mass cultures in the presence of $30 \mu \mathrm{M}$ BMI and $1 \mu \mathrm{M}$ TTX to block $\mathrm{GABA}_{\mathrm{A}}$ receptors and evoked EPSCs, respectively. As for the microisland neurons, $1 \mu \mathrm{M}$ somatostatin shifted the duration of inter-mEPSC intervals to higher values, whereas the distribution of mEPSC amplitudes remained unchanged (Fig. 5A). Seglitide and octreotide, both at $1 \mu \mathrm{M}$, 
$\mathbf{A}$

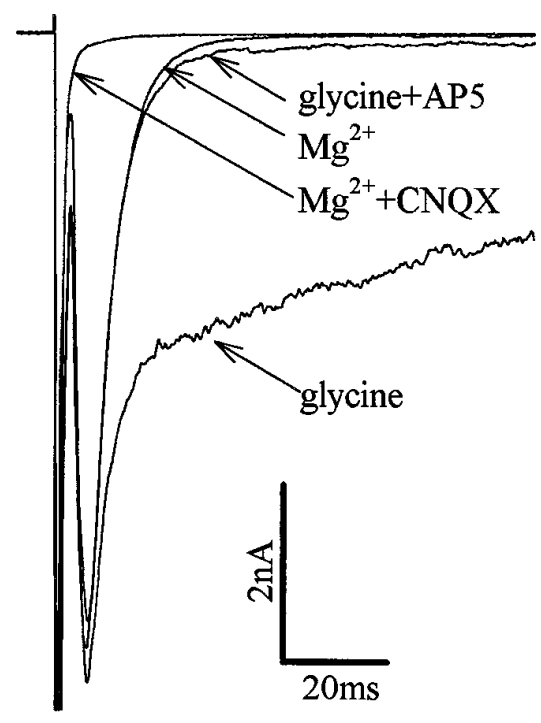

B

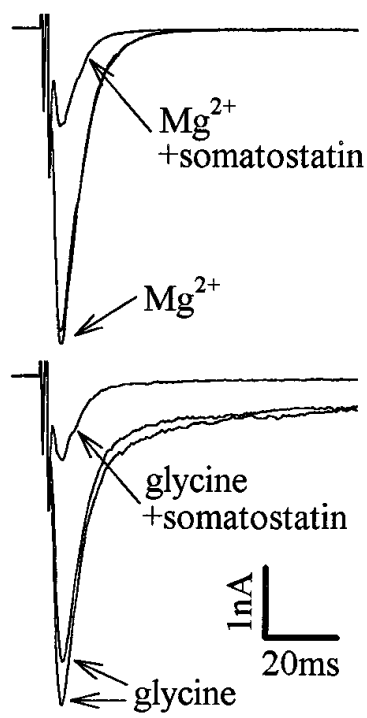

Figure 3. Somatostatin acts at presynaptic receptors. $A$ shows EACs recorded at $-70 \mathrm{mV}$ in the presence of $2 \mathrm{~mm}$ $\mathrm{Mg}^{2+}$, in the presence of $2 \mathrm{mM} \mathrm{Mg}^{2+}+10 \mu \mathrm{M} \mathrm{CNQX}$, after replacement of $\mathrm{Mg}^{2+}$ by $10 \mu \mathrm{M}$ glycine, and after addition of $50 \mu \mathrm{M}$ AP5. $B$ shows the inhibition of EACs by somatostatin in a different microisland neuron in the presence of $2 \mathrm{mM}$ $\mathrm{Mg}^{2+}$ (top traces) and after replacement of $\mathrm{Mg}^{2+}$ by $10 \mu \mathrm{M}$ glycine (bottom traces). Currents were obtained before, during, and after the application of $1 \mu \mathrm{M}$ somatostatin. $C$, Currents evoked by $100 \mu \mathrm{M}$ glutamate at $-70 \mathrm{mV}$ in a mass culture neuron in the presence of $1 \mu \mathrm{M}$ somatostatin, as well as before and after application of the peptide.

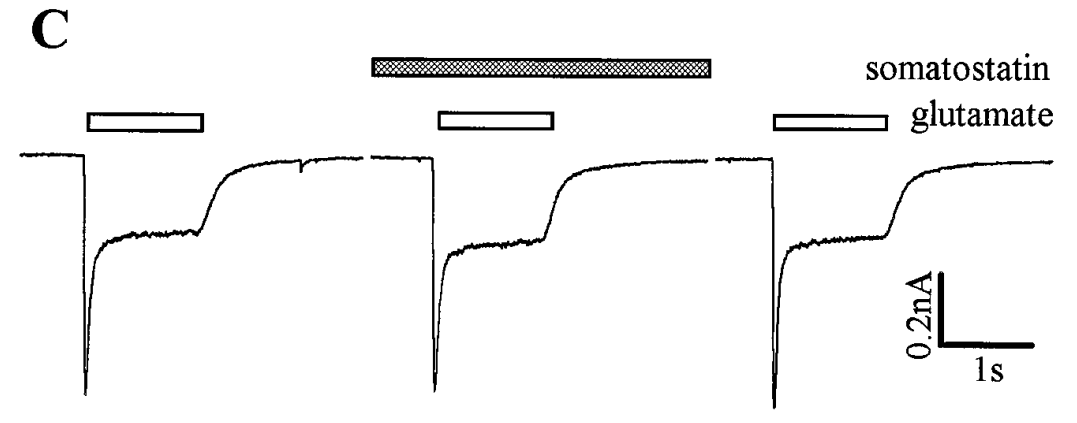

increased mean inter-mEPSC intervals to the same extent as somatostatin, without causing changes in mean mEPSC amplitudes (Fig. 5B). These results corroborate the pharmacological characteristics obtained with EACs.

Subsequently, we also measured mEPSCs in the presence of $100 \mu \mathrm{M} \mathrm{Cd}{ }^{2+}$, which entirely blocks voltage-activated $\mathrm{Ca}^{2+}$ channels and thereby abolishes EACs (see above). Frequencies and amplitudes of mEPSCs determined in the presence of both TTX and $\mathrm{Cd}^{2+}$ were not different from those in the presence of TTX alone (data not shown). Somatostatin increased inter-mEPSC intervals in the presence of $\mathrm{Cd}^{2+}$ to about the same extent as in its absence (Fig. 5C). Thus, these effects of somatostatin on spontaneous glutamate release were independent of transmembrane $\mathrm{Ca}^{2+}$ entry. The reduction in the frequency of mEPSCs by somatostatin was abolished after pretreatment of the cultures with PTX ( $200 \mathrm{ng} / \mathrm{ml}$ for $\geq 24 \mathrm{hr}$ ) (Fig. 5D), which per se did not significantly alter the frequency or the amplitudes of mEPSCs (data not shown). Hence, $\mathrm{G}_{\mathrm{i}} / \mathrm{G}_{\mathrm{o}}$-type $\mathrm{G}$-proteins also mediate the effects of presynaptic $\mathrm{SRIF}_{1}$ receptors on glutamate release, which occur downstream of $\mathrm{Ca}^{2+}$ entry.

\section{Somatostatin receptors reduce voltage-activated $\mathrm{Ca}^{2+}$ currents}

In most instances, presynaptic receptors reduce transmitter release via an inhibition of voltage-gated $\mathrm{Ca}^{2+}$ channels (Boehm and Huck, 1996b; Scholz and Miller, 1996; Takahashi et al., 1996). Somatostatin has been shown previously to reduce voltageactivated $\mathrm{Ca}^{2+}$ currents in various neuronal preparations (for review, see Inoue and Yoshi, 1992). This effect has also been found in pyramidal cells acutely dissociated from the rat hippocampal CA1 region (Ishibashi and Akaike, 1995), but not in the very same neurons when investigated in brain slices (Schweitzer et al., 1993). At present, an effect of somatostatin on $\mathrm{Ca}^{2+}$ currents in hippocampal neurons in cell culture has not been reported. Therefore, we investigated whether somatostatin might modulate the function of $\mathrm{Ca}^{2+}$ channels under our culture conditions. To this end, $\mathrm{Ca}^{2+}$ currents were recorded at neuronal somata in the whole-cell patch-clamp configuration (Hamill et al., 1981). Step depolarizations from $-80 \mathrm{mV}$ to $0 \mathrm{mV}$ elicited rapidly activating currents that reached peak amplitudes of $-0.44 \pm 0.03 \mathrm{nA}$ within $7.7 \pm 0.9 \mathrm{msec}$ after the depolarizing voltage step. In several cases, $\mathrm{Ca}^{2+}$ current kinetics were distorted, presumably because of space clamp problems, and then the recordings were discontinued. In 17 of 21 neurons tested, $1 \mu \mathrm{M}$ somatostatin reduced peak current amplitudes in an entirely reversible manner. In addition, somatostatin delayed activation kinetics (Fig. 6A) so that the mean time to peak was approximately doubled $(15.3 \pm 1.5 \mathrm{msec}$, $n=17 ; p<0.001$ vs control). In current-voltage curves, the inhibitory action of the peptide decreased as the depolarizing 


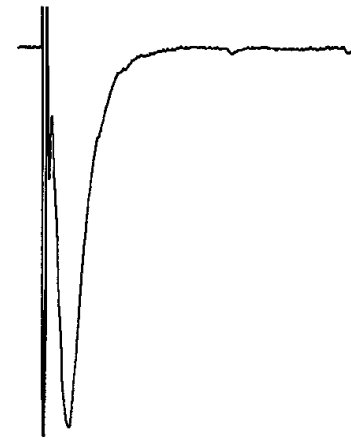

control

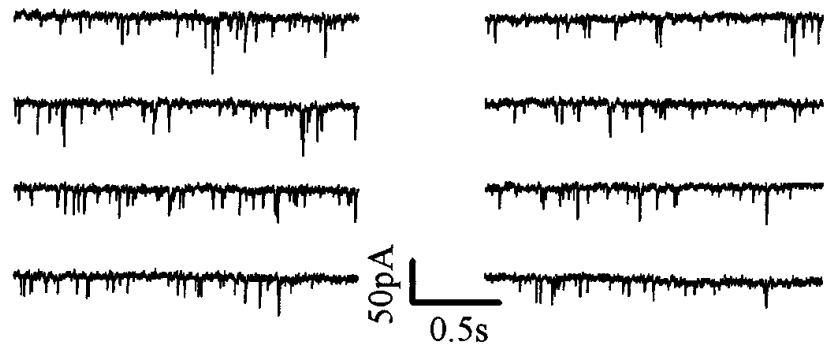

voltage step increased (Fig. 6B,C). Furthermore, facilitation of $\mathrm{Ca}^{2+}$ currents by depolarizing prepulses $(+100 \mathrm{mV}$ for $50 \mathrm{msec}$, followed by a $5 \mathrm{msec}$ repolarization to $-80 \mathrm{mV}$ ) abolished the slowing of activation kinetics by somatostatin and attenuated the reduction of peak current amplitudes (Fig. 6A, inset). Hence, the somatostatin-induced inhibition displayed the characteristics of a G-protein-mediated voltage-dependent modulation of $\mathrm{Ca}^{2+}$ channels (Zhang et al., 1996), which has been described for somatostatin in other preparations (Ishibashi and Akaike, 1995; Toth et al., 1996; Zhang et al., 1996).

The inhibition of $\mathrm{Ca}^{2+}$ currents by somatostatin was halfmaximal at $53 \mathrm{nM}$ and reached a maximum of $26.1 \pm 1.6 \%$ inhibition at $1 \mu \mathrm{M}(n=7)$. Seglitide $(1 \mu \mathrm{M})(25.2 \pm 4.2 \%$ inhibition, $n=6)$ and octreotide $(1 \mu \mathrm{M})(21.3 \pm 4.1 \%$ inhibition; $n=8$ ), when tested in neurons showing a somatostatin-induced inhibition of $\mathrm{Ca}^{2+}$ currents, reduced peak current amplitudes to the same extent as $1 \mu \mathrm{M}$ somatostatin $(21.1 \pm 4.1 \%$ inhibition; $n=$ 10). Thus, the somatostatin receptors that control somatic $\mathrm{Ca}^{2+}$ channels belong to the same receptor subfamily as the presynaptic receptors that inhibit glutamate release.

As mentioned above, the function of presynaptic receptors was abolished by PTX. Likewise, somatostatin failed to affect peak $\mathrm{Ca}^{2+}$ current amplitudes $(0.4 \pm 1.3 \%$ inhibition, $n=11)$ when neurons had been treated with $100 \mathrm{ng} / \mathrm{ml}$ PTX for $\geq 24 \mathrm{hr}$. Peak amplitudes measured in the absence of the peptide were not altered with PTX treatment $(-0.43 \pm 0.06 \mathrm{nA} ; n=11)$. Hence, the effect of somatostatin receptors on somatic $\mathrm{Ca}^{2+}$ channels was also mediated by $\mathrm{G}$-proteins of the $\mathrm{G}_{\mathrm{i}} \mathrm{G}_{\mathrm{o}}$ subtype.

The somatostatin-induced inhibition of $\mathrm{Ca}^{2+}$ currents occurred at higher concentrations than that of EACs (half-maximal effects at $53 \mathrm{nM}$ vs $12 \mathrm{nM}$ ) and reached a maximum of $26 \%$ reduction in $\mathrm{Ca}^{2+}$ current amplitudes compared with the $38 \%$ reduction of EAC amplitudes. Considering that postsynaptic currents are connected to presynaptic $\mathrm{Ca}^{2+}$ influx via a fourth-power relation (Borst and Sakmann, 1996), these results appear inconsistent. Similar discrepancies have been described previously for soma-

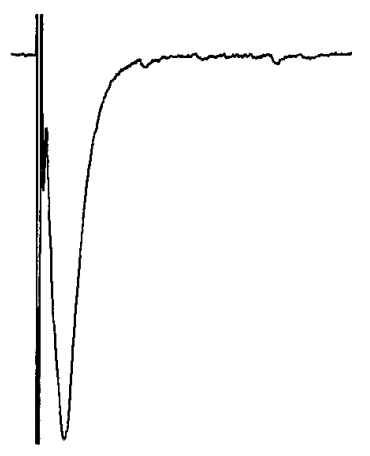

washout

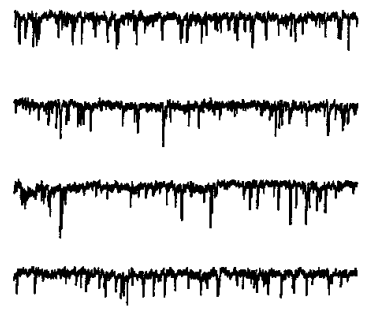

Figure 4. Somatostatin inhibits evoked as well as spontaneous EACs in microisland neurons. Recordings were obtained at $-70 \mathrm{mV}$, and evoked EACs were elicited every $30 \mathrm{sec}$ by $1 \mathrm{msec}$ depolarizations to $0 \mathrm{mV}$. SEACs were recorded intermittently in sweeps of $2 \mathrm{sec}$. Current traces were obtained before (control), during, and after (washout) the application of $1 \mu \mathrm{M}$ somatostatin.

tostatin receptors in peripheral neurons and may indicate that the coupling between $\mathrm{G}$-proteins and voltage-activated $\mathrm{Ca}^{2+}$ channels differs between neuronal somata and presynaptic nerve terminals (Boehm and Huck, 1996a).

\section{Lack of evidence for somatostatin-induced alterations in $\mathrm{K}^{+}$currents}

Apart from voltage-dependent $\mathrm{Ca}^{2+}$ channels, somatostatin receptors are known to modulate neuronal $\mathrm{K}^{+}$channels (Inoue and Yoshi, 1992; Rens-Domiano and Reisine, 1992). In hippocampal CA1 pyramidal neurons in brain slices, somatostatin has been reported to increase $\mathrm{M}$ currents, but no other $\mathrm{K}^{+}$conductances (Moore et al., 1988). To clarify whether somatostatin might affect transmitter release by an alteration in $\mathrm{K}^{+}$conductance, we also measured $\mathrm{K}^{+}$currents at neuronal somata and used step depolarizations from -80 to $0 \mathrm{mV}$, as above. $\mathrm{K}^{+}$currents rapidly (time to peak, $4.4 \pm 0.2 \mathrm{msec} ; n=8)$ reached peak amplitudes $(2.0 \pm$ $0.2 \mathrm{nA} ; n=8$ ) and then decreased to approach a level of steady-state current (Fig. $7 A$ ). Somatostatin $(1 \mu \mathrm{M})$ had no effect on these currents (Fig. $7 A$ ), and peak current amplitudes in the presence of the peptide were $98.2 \pm 0.8 \%$ of control $(n=8)$. To rule out that somatostatin affected $\mathrm{K}^{+}$conductances at other voltages, outward currents were elicited by ramp depolarizations from -70 to $+50 \mathrm{mV}$. In these experiments, somatostatin also failed to cause obvious alterations (Fig. $7 B$ ). Finally, the resting membrane potential of hippocampal neurons in the whole-cell patch-clamp configuration $(-63.1 \pm 5.5 \mathrm{mV}, n=5)$ also was not altered by somatostatin $(-63.3 \pm 6.0 \mathrm{mV} ; n=5)$.

\section{DISCUSSION}

Presynaptic receptors for somatostatin have been described previously in peripheral cholinergic (Gray et al., 1989) and noradrenergic (Boehm and Huck, 1996a) neurons. In the present study, we show that somatostatin also regulates neurotransmission at excitatory central synapses via presynaptic receptors. 

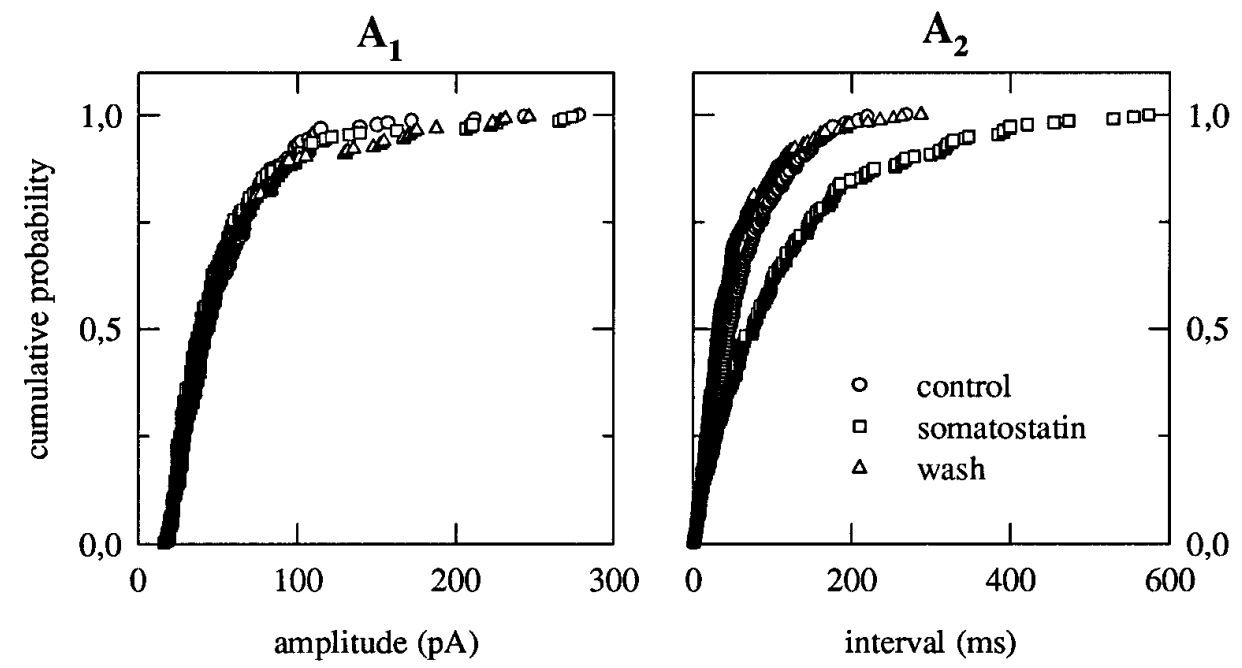

Figure 5. Somatostatin receptors inhibit mEPSCs in hippocampal mass culture neurons. $A$, MEPSCs were recorded in a mass culture neuron at -70 $\mathrm{mV}$ in $1 \mathrm{sec}$ sweeps in the presence of 1 $\mu \mathrm{M}$ TTX and $30 \mu \mathrm{M}$ BMI. More than 200 events were evaluated from recordings obtained before (control), during, and after (wash) the application of $1 \mu \mathrm{M}$ somatostatin. The distribution of mEPSC amplitudes $\left(A_{1}\right)$ and intermEPSC intervals $\left(A_{2}\right)$ is shown. $B$, Effects of $1 \mu \mathrm{M}$ of somatostatin, seglitide, and octreotide on mean mEPSC amplitudes and mean inter-mEPSC intervals of five to six mass culture neurons. Results are shown as percentage of control. Changes in mean intervals $(>50$ events for each condition) were significant $(p<0.05)$ in each neuron. $C$, Effects of somatostatin on mEPSCs recorded as in $A$ and $B$, but in the presence of $100 \mu \mathrm{M} \mathrm{Cd}^{2+}(n=5)$. Changes in mean intervals were significant $(p<$ 0.05 ) in each neuron. $D$, Effects of somatostatin on mEPSCs recorded as in $A-C$, but in neurons treated for $\geq 24 \mathrm{hr}$ with $200 \mathrm{ng} / \mathrm{ml}$ PTX $(n=5)$. Note the loss of somatostatin effects.
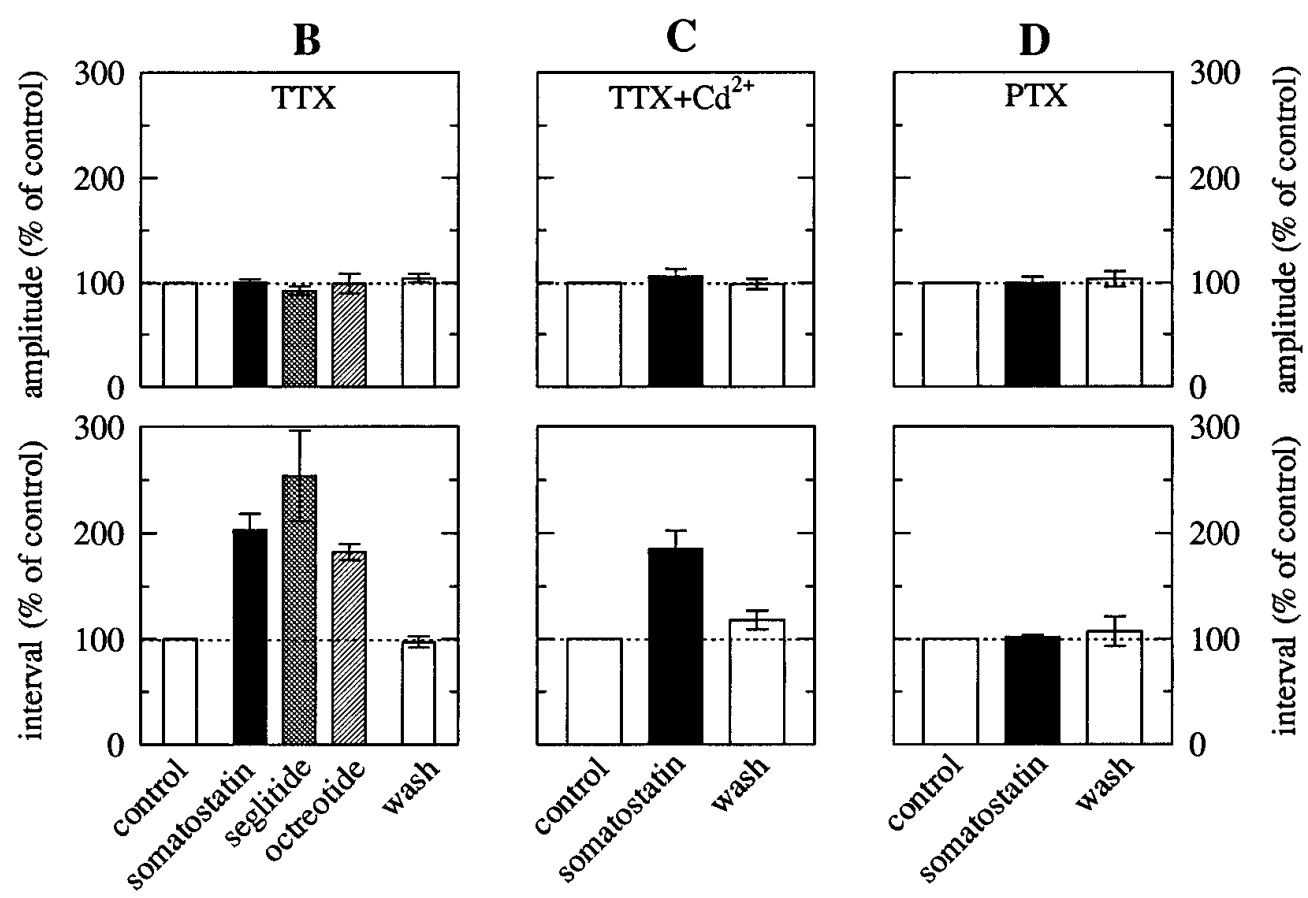

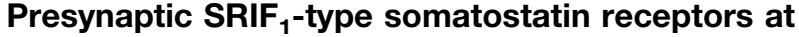 glutamatergic hippocampal synapses}

The measurement of autaptic currents in isolated microisland neurons (Bekkers and Stevens, 1991) permits the detection of effects at homogenous populations of synapses derived from a single neuronal soma. Somatostatin reduced EACs only, and not IACs, which indicated that the peptide did not affect a common step of synaptic transmission in a nonspecific manner. Indeed, all the results obtained in the present study support the idea that somatostatin acted via specific receptors. (1) All actions of somatostatin were abolished when neurons had been pretreated with PTX. Hence, effects were mediated by $\mathrm{G}_{\mathrm{i}} / \mathrm{G}_{\mathrm{o}}$-type G-proteins, a class of G-proteins to which all somatostatin receptors may be linked (Hoyer et al., 1994; Reisine and Bell, 1995). (2) The effects of somatostatin were concentration-dependent with half-maximal inhibition in the range of $10^{-8} \mathrm{M}$. The five somatostatin receptors characterized by molecular cloning show comparable affinities for the neuropeptide (Hoyer et al., 1994, 1995). (3) The somatostatin- induced inhibition was mimicked by seglitide and octreotide, short synthetic analog peptides of somatostatin (Veber et al., 1981; Tran et al., 1985).

Submicromolar concentrations of these peptides activate somatostatin receptors of the $\mathrm{SRIF}_{1}$ receptor subfamily (Hoyer et al., 1994). This group of receptors currently harbors the cloned receptors sstr-2, -3 , and -5 (Hoyer et al., 1995; Reisine and Bell, 1995). In our experiments, octreotide and seglitide were equipotent to somatostatin. At sstr-2 receptors, these peptides display the same affinities as somatostatin, whereas at sstr-3, they are less potent. At sstr-5, seglitide has a lower affinity than somatostatin and octreotide (Hoyer et al., 1994). Thus, our results indicate that the presynaptic somatostatin receptors of glutamatergic hippocampal neurons belong to the $\mathrm{SRIF}_{1}$ subfamily and most closely resemble the cloned sstr-2 receptor. However, additional experiments with highly selective agonists (Raynor et al., 1993) are required for additional characterization of these receptors.

Somatostatin receptors have been reported to modulate the 
$\mathbf{A}$

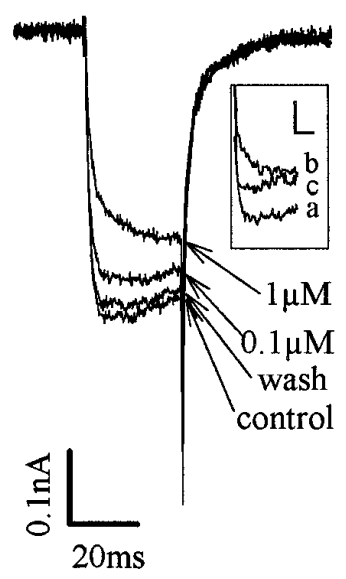

B

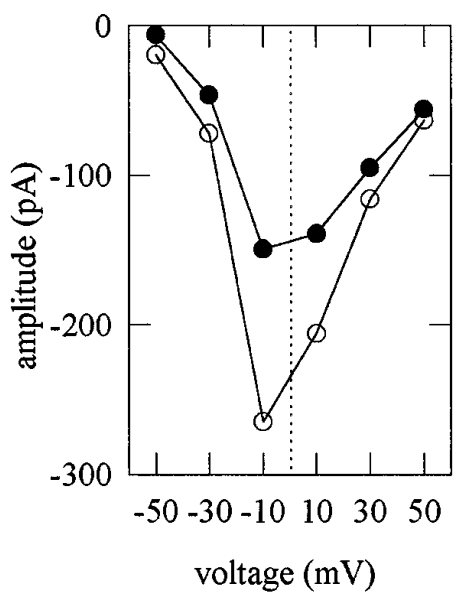

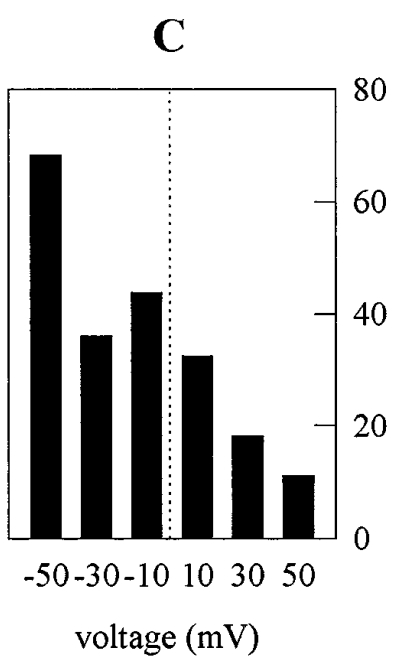

Figure 6. Inhibition of voltageactivated $\mathrm{Ca}^{2+}$ currents by somatostatin. $A, \mathrm{Ca}^{2+}$ currents were evoked in a mass culture neuron by depolarizations from -80 to $0 \mathrm{mV}$. Traces were recorded before (control), during, and after (wash) the application of 0.1 and $1 \mu \mathrm{M}$ somatostatin. The inset shows rising phases of $\mathrm{Ca}^{2+}$ currents in the very same neuron under control conditions $(a)$, in the presence of $1 \mu \mathrm{M}$ somatostatin $(b)$, and in the presence of somatostatin, but subsequent to a $50 \mathrm{msec}$ predepolarization to $+100 \mathrm{mV}$, followed by a $5 \mathrm{msec}$ repolarization to $-80 \mathrm{mV}(c)$. Calibration, $50 \mathrm{pA}, 10 \mathrm{msec} . B$, Current-voltage relationship of the $\mathrm{Ca}^{2+}$ currents in the same neuron as in $A$ before (open circles) and during (solid circles) the application of $1 \mu \mathrm{M}$ somatostatin. $C$, The effect of somatostatin on the currentvoltage relationship in $B$ is shown as percentage of inhibition. function of non-NMDA glutamate receptors (Gardette et al., 1995). Hence, a selective reduction of EACs via somatostatin receptors might involve a postsynaptic site of action. However, we found no evidence for an effect of somatostatin on the function of ionotropic glutamate receptors in rat hippocampal neurons. The observations that somatostatin neither altered glutamate-evoked currents nor affected mEPSC amplitudes both indicate that somatostatin acted via presynaptic receptors.

\section{Signaling mechanisms of presynaptic somatostatin receptors}

All presynaptic receptors that have been identified on rat hippocampal neurons belong to the superfamily of G-proteincoupled receptors, the effects being in many, but not all, cases PTX-sensitive (for review, see Thompson et al., 1993). Most somatostatin receptors are linked to PTX-sensitive G-proteins (Rens-Domiano and Reisine, 1992), and this was also true for the presynaptic receptors investigated in the present study.

A plethora of signaling mechanisms may mediate the regulation of synaptic transmitter release by heterotrimeric GTP-binding proteins (for review, see Fang et al., 1994). Intraneuronal effector systems for somatostatin receptors include various types of $\mathrm{K}^{+}$ channels, which may be activated, and voltage-gated $\mathrm{Ca}^{2+}$ channels, which may be inhibited (Inoue and Yoshi, 1992). Each of these effects could reduce depolarization-evoked transmitter release. In our experiments, we were unable to detect any effect of somatostatin on $\mathrm{K}^{+}$currents. Previously, somatostatin has been found to selectively increase one type of $\mathrm{K}^{+}$current, the $\mathrm{M}$ current, in rat CA1 pyramidal neurons (Moore et al., 1988).
However, it appears unlikely that an increase in $M$ currents contributed to the presynaptic inhibition described here, for the following reasons. (1) Somatostatin receptors and muscarinic acetylcholine receptors modulate $\mathrm{M}$ currents of hippocampal neurons in opposite directions (Inoue and Yoshi, 1992), but both types of receptors inhibit excitatory synaptic transmission (Scanziani et al., 1995; present study). (2) Despite the modulation of $\mathrm{K}_{\mathrm{M}}$ channels by somatostatin, the peptide has almost no effect on action potentials (Schweitzer et al., 1993) that represent the link between the depolarization of neuronal somata and $\mathrm{Ca}^{2+}$ entry as well as transmitter release at autapses (as evidenced by the inhibitory action of TTX).

In contrast, somatostatin receptors with pharmacological characteristics identical to those of the presynaptic receptors investigated here reduced voltage-activated $\mathrm{Ca}^{2+}$ currents at the somata of hippocampal neurons. Inhibition of $\mathrm{Ca}^{2+}$ entry at presynaptic terminals has been shown to induce inhibition of glutamatergic transmission (Takahashi et al., 1996). Therefore, we assume that the somatostatin-induced reduction of $\mathrm{Ca}^{2+}$ influx also occurred at presynaptic nerve terminals and caused the inhibition of transmitter release. In peripheral neurons, the inhibition of voltagegated $\mathrm{Ca}^{2+}$ channels appears to represent the only mechanism by which presynaptic somatostatin receptors reduce transmitter release (Gray et al., 1989; Boehm and Huck, 1996a). In hippocampal neurons, the signaling mechanisms of presynaptic somatostatin receptors seem to be more diverse, because agonists reduced the frequency of mEPSCs even in the presence of $\mathrm{Cd}^{2+}$. Hence, like many other presynaptic receptors of hippocampal neurons

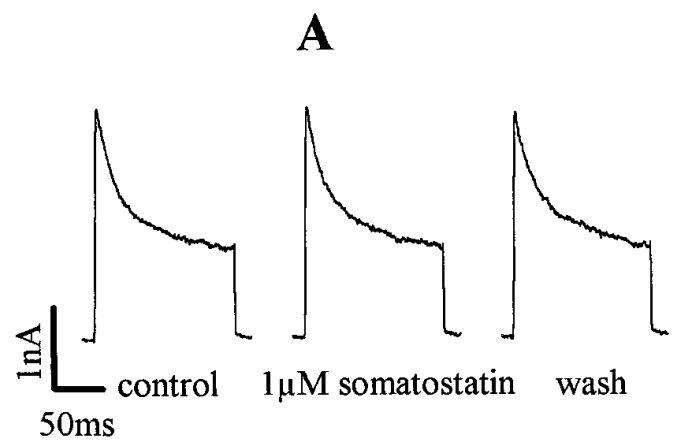

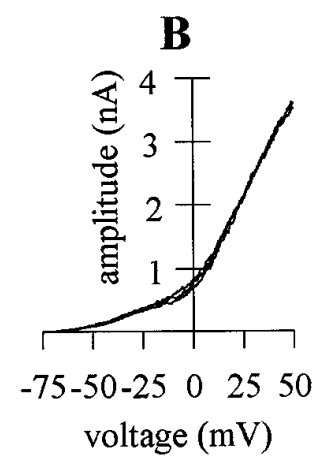

Figure 7. Lack of effect of somatostatin on voltagedependent $\mathrm{K}^{+}$currents. $A, \mathrm{~K}^{+}$currents in a mass culture neuron were evoked by depolarizations from -80 to $0 \mathrm{mV}$ before (control), during, and after (wash) the application of $1 \mu \mathrm{M}$ somatostatin. $B$, Outward currents in a mass culture neuron were induced by a $0.2 \mathrm{sec}$ ramp depolarization from -70 to $+50 \mathrm{mV}$ before, during, and after the application of $1 \mu \mathrm{M}$ somatostatin. Note that three traces are superimposed because of the lack of action of somatostatin. 
(Scanziani et al., 1992; Scholz and Miller, 1992; Thompson et al., 1993; Trudeau et al., 1996), presynaptic somatostatin receptors may reduce excitatory synaptic transmission via at least two independent signaling mechanisms: an inhibition of $\mathrm{Ca}^{2+}$ entry and a reduction of vesicle exocytosis, which arises downstream of $\mathrm{Ca}^{2+}$ entry.

Whether the modulation of $\mathrm{Ca}^{2+}$ channels or the action downstream of $\mathrm{Ca}^{2+}$ entry mediates the inhibition of action potentialevoked transmitter release most likely depends on the organization of synaptic transmission. At hippocampal synapses, N- and Q-type $\mathrm{Ca}^{2+}$ channels contribute to synaptic transmission (Wheeler et al., 1994). N-type channels provide $\sim 50 \%$ of the $\mathrm{Ca}^{2+}$ entry necessary for transmission (Wheeler et al., 1994, 1996), and these channels are preferentially inhibited by somatostatin receptors (Toth et al., 1996; Zhang et al., 1996). Hence, under physiological conditions in which postsynaptic responses are proportional to the fourth power of the presynaptic $\mathrm{Ca}^{2+}$ current (Borst and Sakmann, 1996), reduction of currents through one type of $\mathrm{Ca}^{2+}$ channel may be sufficient to cause inhibition of transmitter release. If, however, the contribution of one type of $\mathrm{Ca}^{2+}$ channel becomes redundant, for example, by broadening of action potentials (Wheeler et al., 1996) during neuronal bursting (see Kaczmarek and Levitan, 1987), a modulation of this channel will be ineffective. Furthermore, the inhibition of all types of neuronal $\mathrm{Ca}^{2+}$ currents via G-proteins is largely attenuated or abolished when depolarizations are applied at short intervals $(<50 \mathrm{msec})$ (Grassi and Lux, 1989; Toth et al., 1996; Zhang et al., 1996). Hence, high-frequency firing may also hinder the receptor-mediated modulation of $\mathrm{Ca}^{2+}$ channels. Taken together, the dual signaling cascade of presynaptic somatostatin receptors may serve to control excitatory transmission not only under physiological conditions, but also when transmission occurs at higher frequencies, for example, during seizure-like activity.

\section{Functional significance of presynaptic somatostatin receptors in the hippocampus}

The function of many neuropeptides under physiological conditions is unclear, but it is believed to be important in pathology (Hökfelt, 1991). Somatostatin, in analogy to neuropeptide Y, has been suggested to play a role in hippocampal epilepsy (for Review, see Schwarzer et al., 1996). Neuropeptide y has long been recognized to reduce excitatory transmission in the hippocampus (Colmers et al., 1985), an action that forms the basis for the anticonvulsant activity of that peptide (Woldbey et al., 1996).

In the present study, we showed that somatostatin acting at presynaptic $\mathrm{SRIF}_{1}$ receptors (most probably at sstr-2) reduced synaptic glutamate release from hippocampal neurons in vitro. Provided this effect also occurs in vivo, activation of presynaptic somatostatin receptors may represent a mechanism to reduce epileptic seizures and subsequent neuronal damage in the hippocampus. In vivo antiepileptic activity of somatostatin (Monno et al., 1993) and sstr-2-preferring agonists (Perez et al., 1995), including octreotide (Vezzani et al., 1991), has indeed been reported. Hence, additional investigation of presynaptic somatostatin receptors in hippocampal neurons under in vivo conditions may have therapeutic promise for temporal lobe epilepsy.

\section{REFERENCES}

Araujo DM, Lapchak PA, Collier B, Quirion R (1990) Evidence that somatostatin enhances endogenous acetylcholine release in the rat hippocampus. J Neurochem 55:1546-1555.

Bekkers JM, Stevens CF (1991) Excitatory and inhibitory autaptic currents in isolated hippocampal neurons maintained in cell culture. Proc Natl Acad Sci USA 88:7834-7838.
Boehm S, Huck S (1996a) A somatostatin receptor inhibits noradrenaline release from chick sympathetic neurons through pertussis toxinsensitive mechanisms: comparison with the action of alpha2adrenoceptors. Neuroscience 73:595-604.

Boehm S, Huck S (1996b) Inhibition of N-type calcium channels: the only mechanism by which presynaptic $\alpha_{2}$-autoreceptors control sympathetic transmitter release. Eur J Neurosci 8:1924-1931.

Boehm S, Huck S, Freissmuth M (1996) Involvement of a phorbol esterinsensitive protein kinase $\mathrm{C}$ in the alpha $_{2}$-adrenergic inhibition of voltage-gated $\mathrm{Ca}^{2+}$ current in chick sympathetic neurons. J Neurosci 16:4596-4603.

Borst JGG, Sakmann B (1996) Calcium influx and transmitter release at a fast CNS synapse. Nature 383:431-434.

Brazeau P, Vale W, Burgus R, Ling N, Butcher M, Rivier J, Guillemin R (1973) Hypothalamic polypeptide that inhibits the secretion of immunoreactive pituitary growth hormone. Science 179:77-79.

Chesselet MF, Reisine T (1983) Somatostatin regulates dopamine release in rat striatal slices and cat caudate nuclei. J Neurosci 3:232-236.

Colmers WF, Lukowiak KD, Pittman QJ (1985) Neuropeptide Y reduces orthodromically evoked population spikes in rat hippocampal CA1 by a possibly presynaptic mechanism. Brain Res 346:404-408.

Davies P, Katzmann R, Terry RD (1980) Reduced somatostatin-like immunoreactivity in cerebral cortex from cases of Alzheimer disease and Alzheimer senile dementia. Nature 288:279-280.

Delfs JR, Dichter MA (1983) Effects of somatostatin on mammalian cortical neurons in culture: physiological actions and unusual dose response characteristics. J Neurosci 3:1176-1186.

DeLean A, Munson PJ, Rodbard D (1978) Simultaneous analysis of families of sigmoidal curves: application to bioassay, radioligand assay, and physiological dose-response curves. Am J Physiol 235:E97-E102.

Dodd J, Kelly JS (1978) Is somatostatin an excitatory transmitter in the hippocampus? Nature 273:674-675.

Fang Y, Durgerian S, Basarsky TA, Haydon PG (1994) GTP-binding proteins: necessary components of the presynaptic terminal for synaptic transmission and its modulation. Adv Second Messenger Phosphoprotein Res 29:121-132.

Fontana G, De Bernardi R, Ferro F, Gemignani A, Raiteri M (1996) Characterization of the glutamate receptors mediating release of somatostatin from cultured hippocampal neurons. J Neurochem 66:161-168.

Freund TF, Buzsaki G (1996) Interneurons of the hippocampus. Hippocampus 6:347-470.

Gardette R, Faivre-Baumann A, Loudes C, Kordon C, Epelbaum J (1995) Modulation by somatostatin of glutamate sensitivity during development of mouse hypothalamic neurons in vitro. Dev Brain Res 86:123-133.

Grassi F, Lux HD (1989) Voltage-dependent GABA-induced modulation of calcium currents in chick sensory neurons. Neurosci Lett 105:113-119.

Gray DB, Pilar GR, Ford MJ (1989) Opiate and peptide inhibition of transmitter release in parasympathetic nerve terminals. J Neurosci 9:1683-1692.

Hamill OP, Marty A, Neher E, Sakmann B, Sigworth FJ (1981) Improved patch clamp techniques for high-resolution current recording from cells and cell-free membrane patches. Pflügers Arch 391:85-100.

Hökfelt T (1991) Neuropeptides in perspective: the last ten years. Neuron $7: 867-879$.

Hoyer D, Lübbert H, Bruns C (1994) Molecular pharmacology of somatostatin receptors. Naunyn Schmiedebergs Arch Pharmacol 350:441-453.

Hoyer D, Bell GI, Berelowitz M, Epelbaum J, Feniuk W, Humphrey PPA, O'Carroll AM, Patel YC, Schonbrunn A, Taylor JE, Reisine T (1995) Classification and nomenclature of somatostatin receptors. Trends Pharmacol Sci 16:86-88.

Inoue M, Yoshi M (1992) Modulation of ion channels by somatostatin and acetylcholine. Prog Neurobiol 38:203-230.

Ishibashi H, Akaike N (1995) Somatostatin modulates high-voltageactivated $\mathrm{Ca}^{2+}$ channels in freshly dissociated rat hippocampal neurons. J Neurophysiol 74:1028-1036.

Iversen LL, Iversen SD, Bloom F, Douglas C, Brown M, Vale W (1978) Calcium-dependent release of somatostatin and neurotensin from rat brain in vitro. Nature 273:161-163.

Johansson O, Hökfelt T, Elde RP (1984) Immunohistochemical distribution of somatostatin-like immunoreactivity in the central nervous system of the rat. Neuroscience 13:265-339.

Kaczmarek LK, Levitan IB (1987) What is neuromodulation? In: Neu- 
romodulation: the biochemical control of neural excitability (Kaczmarek LK, Levitan IB, eds), pp 3-17. New York: Oxford UP.

Kuriashi Y, Hirota N, Sato Y, Hino Y, Satoh M, Takagi H (1985) Evidence that substance $\mathrm{P}$ and somatostatin transmit separate information related to pain in the spinal dorsal horn. Brain Res 325:294-298.

Mathe AA, Nomikos GG, Svensson TH (1993) In vivo release of somatostatin from rat hippocampus and striatum. Neurosci Lett 149:201-204.

Matsuoka N, Maeda N, Yamaguchi I, Satoh M (1994) Possible involvement of brain somatostatin in the memory formation of rats and the cognitive enhancing action of FR121196 in passive avoidance task. Brain Res 642:11-19.

Monno A, Rizzi M, Samanin R, Vezzani A (1993) Anti-somatostatin antibody enhances the rate of hippocampal kindling in rats. Brain Res 602:148-152.

Moore SD, Madamba S, Joels M, Siggins GR (1988) Somatostatin augments the M-current in hippocampal neurons. Science 239:278-280.

Pittman QJ, Siggins GR (1981) Somatostatin hyperpolarizes hippocampal pyramidal cells in vitro. Brain Res 221:402-408.

Perez J, Vezzani A, Civenni G, Tutka P, Rizzi M, Schüpbach E, Hoyer D (1995) Functional effects of D-Phe-c[Cys-Tyr-D-Trp-Lys-Val-Cys]-Trp$\mathrm{NH}_{2}$ and differential changes in somatostatin receptor messenger RNAs, binding sites and somatostatin release in kainic acid-treated rats. Neuroscience 65:1087-1097.

Raynor K, Murphy WA, Coy DH, Moreau JP, Yasuda K, Bell GI, Reisine T (1993) Cloned somatostatin receptors: identification of subtype selective peptides and demonstration of high affinity binding of linear peptides. Mol Pharmacol 43:838-844.

Reichlin S (1983) Somatostatin. N Engl J Med 309:1495-1501, 1556-1563.

Reisine T, Bell GI (1995) Molecular properties of somatostatin receptors. Neuroscience 67:777-790.

Rens-Domiano S, Reisine T (1992) Biochemical and functional properties of somatostatin receptors. J Neurochem 58:1987-1996.

Robbins RJ, Brines ML, Kim JH, Adrian T, deLannerolle N, Welsh MS, Spencer DD (1991) A selective loss of somatostatin in the hippocampus of patients with temporal lobe epilepsy. Ann Neurol 29:325-332.

Scanziani M, Capogna M, Gähwiler BH, Thompson SM (1992) Presynaptic inhibition of miniature excitatory synaptic currents by baclofen and adenosine in the hippocampus. Neuron 9:919-927.

Scanziani M, Gähwiler BH, Thompson SM (1995) Presynaptic inhibition of excitatory transmission by muscarinic and metabotropic glutamate receptor activation in the hippocampus: are $\mathrm{Ca}^{2+}$ channels involved? Neuropharmacology 34:1549-1557.

Scholz KP, Miller RJ (1992) Inhibition of quantal transmitter release in the absence of $\mathrm{Ca}^{2+}$ influx by a $\mathrm{G}$ protein linked adenosine receptor at hippocampal synapses. Neuron 8:1139-1150.

Scholz KP, Miller RJ (1996) Presynaptic inhibition at excitatory hippocampal synapses: development and role of presynaptic $\mathrm{Ca}^{2+}$ channels. J Neurophysiol 76:49-46.

Schwarzer C, Sperk G, Samanin R, Rizzi M, Gariboldi M, Vezzani A (1996) Neuropeptides-immunoreactivity and their mRNA expression in kindling: functional implications for limbic epileptogenesis. Brain Res Rev 22:27-50.
Schweitzer P, Madamba S, Champagnat J, Siggins GR (1993) Somatostatin inhibition of hippocampal CA1 pyramidal neurons: mediation by arachidonic acid and its metabolites. J Neurosci 13:2033-2049.

Takahashi T, Forsythe ID, Tsujimoto T, Barnes-Davies M, Onodera K (1996) Presynaptic calcium current modulation by a metanotropic glutamate receptor. Science 274:594-597.

Thompson SM, Capogna M, Scanziani M (1993) Presynaptic inhibition in the hippocampus. Trends Neurosci 16:222-227.

Thoss VS, Perez J, Duc D, Hoyer D (1995) Embryonic and postnatal mRNA distribution of five somatostatin receptor subtypes in the rat brain. Neuropharmacology 34:1673-1688.

Tong G, Malenka RC, Nicoll RA (1996) Long-term potentiation in cultures of single hippocampal granule cells: a presynaptic form of plasticity. Neuron 16:1147-1157.

Toth PT, Shekter LR, Hui Ma G, Philipson LH, Miller RJ (1996) Selective $G$ protein regulation of neuronal calcium channels. J Neurosci 16:4617-4624.

Tran VT, Beal MF, Martin JB (1985) Two types of somatostatin receptors differentiated by cyclic somatostatin analogs. Science 228:492-495.

Trudeau LE, Doyle RT, Emery DG, Haydon PG (1996) Calciumindependent activation of the secretory apparatus by ruthenium red in hippocampal neurons: a new tool to assess modulation of presynaptic function. J Neurosci 16:46-54.

Twery MJ, Wong LA, Gallagher JP (1991) Somatostatin induced hyperpolarization of septal neurons is not blocked by pertussis toxin. Eur J Pharmacol 192:287-291.

Veber DF, Freidinger RM, Schwenk Perlow D, Paleveda Jr WJ, Holly FW, Strachan RG, Nutt RF, Arison BH, Homnick C, Randall WC, Glitzer MS, Saperstein R, Hirschmann R (1981) A potent cyclic hexapeptide analogue of somatostatin. Nature 292:55-58.

Vezzani A, Serafini R, Stasi MA, Vigano G, Rizzi M, Samanin R (1991) A peptidase resistant cyclic octapeptide analogue of somatostatin (SMS 201-995) differently modulates seizures induced by quinolinic and kainic acid in the rat hippocampus. Neuropharmacology 30:345-352.

Wang HL, Dichter M, Reisine T (1990) Lack of cross-desensitization of somatostatin-14 and somatostatin-28 receptors coupled to potassium channels in rat neocortical neurons. Mol Pharmacol 38:357-361.

Wheeler DB, Randall A, Tsien RW (1994) Roles of N-type and Q-type $\mathrm{Ca}^{2+}$ channels in supporting hippocampal synaptic transmission. Science 264:107-111.

Wheeler DB, Randall A, Tsien RW (1996) Changes in action potential duration alter reliance of excitatory transmission on multiple types of $\mathrm{Ca}^{2+}$ channels in rat hippocampus. J Neurosci 16:2226-2237.

Woldbey DPD, Madsen TM, Larsen PJ, Mikkelsen JD, Bolwig DG (1996) Neuropeptide Y inhibits hippocampal seizures and wet dog shakes. Brain Res 737:162-168.

Zhang JF, Ellinor PT, Aldrich RW, Tsien RW (1996) Multiple structural elements in voltage-dependent $\mathrm{Ca}^{2+}$ channels support their inhibition by G proteins. Neuron 17:991-1003. 